\title{
Comparison of national cross-sectional breast-feeding surveys by maternal education in Europe (2006-2016)
}

\author{
Mahesh Sarki ${ }^{1}$, Alexandr Parlesak ${ }^{2}$ and Aileen Robertson ${ }^{2, *}$ \\ 'Global Health, University of Copenhagen, Copenhagen, Denmark: ${ }^{2}$ Global Nutrition and Health, University \\ College Copenhagen, Sigurdsgade 26, 2200 København N, Denmark
}

Submitted 1 February 2018: Final revision received 8 July 2018: Accepted 24 September 2018: First published online 5 December 2018

\begin{abstract}
Objective: Breast-feeding is an important determinant of health of mothers and their offspring. The present study aimed to compare breast-feeding rates across Europe disaggregated by maternal education and establish what proportion achieves at least $50 \%$ exclusive breast-feeding (EBF) at 6 months.

Design/Setting: Secondary analysis of national or sub-national studies' breastfeeding data for EU Member States plus Norway and Iceland, published in 20062016. Nineteen EU Member States plus Norway reported rates of EBF and any breast-feeding disaggregated by maternal education, of which only thirteen could be matched to the International Standard Classification of Education.

Participants: Mothers and their infants aged 0-12 months.

Results: Data on EBF rates at 6 and 4 months were found in only four and six countries, respectively. At 6 months, EBF rates of $49 \%$ in Slovakia and $44 \%$ in Hungary were closest to WHO's target of at least $50 \%$ EBF. At 4 months, mothers with high education level in Denmark, the Netherlands and Germany had the highest EBF rates (71, 52 and 50\%, respectively). Mothers with low education level were less likely to initiate breast-feeding and cessation occurred early. The inequality gap ranged from $63 \%$ in Irish mothers to no gap or very low levels of inequality in Poland, Sweden and Norway.

Conclusions: More mothers with high, compared with low, education initiate breast-feeding and practise EBF for longer. More European policies should be targeted to protect, support and promote breast-feeding, especially among mothers with only mandatory education.
\end{abstract}

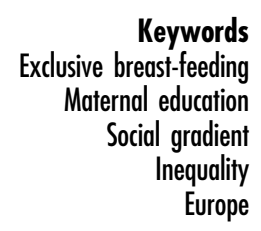

WHO Member States have agreed six Global Targets for Nutrition $^{(1)}$. One target is to increase the rate of exclusive breast-feeding (EBF) in the first 6 months to at least $50 \%$ by 2025 and another target is to halt the increase in childhood overweight. Globally, breast-feeding rates have not improved substantially over recent years and rates of EBF at 6 months are well below the 2025 target in most countries. In low- and middle-income countries reliable monitoring systems report breast-feeding rates less than $40 \% \mathrm{EBF}$ in the first 6 months ${ }^{(2)}$, but the average rates in low- and middleincome countries are high compared with those in highincome countries. Interestingly, it appears in low- and middle-income countries that women with low socioeconomic status (SES) breast-feed longer than those with high SES, in contrast to high-income countries where the trend appears to be in the opposite direction ${ }^{(3)}$. Mothers of low SES in Europe appear less likely to initiate breastfeeding and cessation occurs early compared with those of high $\mathrm{SES}^{(4-7)}$. Moreover, infants who are predominantly formula-fed compared with those being exclusively breastfed for the first 6 months are two-and-a-half times more likely to be obese at 24 months $^{(8)}$ and cessation of EBF before 4 months increases the risk of childhood obesity ${ }^{(9,10)}$. Indeed, the prevalence of obesity is also greater among low- compared with high-SES families ${ }^{(8,11-13)}$ and obese mothers especially have to overcome more barriers when trying to breast-feed ${ }^{(14,15)}$. It has been suggested that an improvement in EBF rates among low-SES mothers could help reduce health inequalities ${ }^{(16,17)}$ related to obesity $^{(16)}$ and resulting morbidity ${ }^{(3,17,18)}$.

Because of the lack of published studies comparing the rates of breast-feeding across socio-economic groups in Europe $^{(19,20)}$, the second recommendation in the report Diet, Nutrition and Obesity: Infant Feeding by Socioeconomic Status stated that:

'Data on breastfeeding prevalence and complementary feeding practices by socio-economic 
status do exist in many EU Member States. ... However, apart from one comparative survey published in 2012 by Ibanez et al., no systematic comparison has been made across EU Member States. It is therefore recommended to collect and compare existing data from each EU Member State on breastfeeding prevalence and complementary feeding practices by socio-economic status (i.e. education, profession, maternity protection, etc.).'

Therefore, the present study aimed to compare breastfeeding rates using the level of maternal education as a proxy for SES ${ }^{(21)}$. Given the health benefits for both mothers and their infants ${ }^{(2)}$, low breast-feeding rates in low-SES families are likely to result in high rates of health inequalities which could be prevented through appropriate policy actions

\section{Methods}

A combination of search methods was used between May 2016 and November 2017. This included an Internet-based search of official websites belonging to national authorities along with websites of national and international organizations dealing with breast-feeding. Where national surveys were not found, databases including MEDLINE, CINAHL, EMBASE, Cochrane, PSYCInfo, PubMed and Google Scholar were searched using the keywords: 'breastfeeding' AND/OR 'infant and young child feeding practices', 'breastfeeding prevalence' and 'breastfeeding statistics'. Data from the most recent breast-feeding survey carried out in each country were sought. The earliest survey was published in 2006 and the most recent in 2016.

To help find surveys published in national languages, Google Translate was used followed by thorough validation of data translations by native speakers knowledgeable about breast-feeding. For example, the national coordinators of the national Baby Friendly Hospital Initiative (Table 1) ${ }^{(22)}$ were asked to confirm national breast-feeding prevalence (personal communications, May-October 2016). Failing contact with a national coordinator, native speakers at the department of Global Nutrition and Health at University College Copenhagen were asked to confirm translations in their national languages.

Twenty-five nationally representative breast-feeding surveys authorized by national authorities were obtained by year of most recent survey: Austria 2007, Belgium 2013, Croatia 2014, Cyprus 2006, Czech Republic 2009, Denmark 2016, Estonia 2016, Finland 2012 and 2009, France 2016, Germany 2015, Greece 2009, Hungary 2014, Iceland 2012, Ireland 2010, Italy 2014, Latvia 2010, Luxembourg 2010, Malta 2015, Netherlands 2015, Poland 2016, Romania 2011, Slovak Republic 2011, Spain 2016, Sweden 2015 and UK 2012. No national studies were found for five countries and for these only sub-national peer-reviewed studies
(Bulgaria 2010, Lithuania 2016, Portugal 2007, Slovenia 2010 and Norway 2010) were found. One peer-reviewed study was found for each of EBF at 4 months in France (2016) and breast-feeding at 1 week in Sweden (2016).

\section{Maternal education level}

Socio-economic position was represented by maternal education level. Education levels were harmonized according to the International Standard Classification of Education (ISCED) ${ }^{(23)}$ and defined in three categories: low $=$ levels $0-2$ (compulsory, i.e. primary or lower secondary education); middle = levels 3-4 (upper secondary and post-secondary non-tertiary education); and high $=$ levels 5-6 (tertiary education; Table 1).

\section{Breast-feeding variables}

For the purpose of comparison, the following breastfeeding variables used in national surveys were grouped together into one variable called 'any breast-feeding (ABF)': breast-feeding within the first hour (recommended by $\mathrm{WHO}^{(24)}$; ever breast-fed; breast-feeding at all; breast-feeding at birth; and breast-feeding at discharge. In addition, rates on 'breast-feeding at 1 week' from Sweden and 'breast-feeding at $<1$ month' from Finland were included in the ABF variable. Three additional ABF variables were created (Table 2) to group the different time frames used in national studies to allow their comparison: 'ABF at $\leq 2$ months', which included $\mathrm{ABF}$ rates from between 1 and 8 weeks; 'ABF at $\leq 4$ months', which included $\mathrm{ABF}$ rates from between 8 and 16 weeks; and 'ABF at 6 months', which included $\mathrm{ABF}$ rates reported at 6 months. Similarly, the wide range of variables used in national surveys to report rates of EBF were grouped together into four variables (Table 3 ). These were based on the different definitions for time frame used in national studies. The variable 'EBF at $\leq 1$ month' included all EBF rates from 1 to 4 weeks. The variable 'EBF at $\leq 3$ months' included all EBF rates from 5 to 12 weeks. The variable 'EBF at 4 months' included all EBF rates relating to 4 months (e.g. EBF up to 4 months and EBF at least until 4 months). The fourth variable was 'EBF at 6 months'.

\section{Inequality gap}

The inequality gap analysis was carried out by calculating the difference between the breast-feeding rates of mothers with the highest minus the lowest level of education, and expressed as a percentage of the rate in the highest education level $^{(25)}$. The breast-feeding rates of mothers with the highest level of education were used as the highest possible achievable rate for that specific country when calculating the inequality gaps. 
Table 1 Levels of maternal education defined according to ISCED classification (low = ISCED 0-2; middle = ISCED 3-4; high = ISCED 5-6)

\begin{tabular}{|c|c|c|}
\hline Country & $\begin{array}{l}\text { Indicators used for level of maternal education in } \\
\text { national surveys or studies }\end{array}$ & $\begin{array}{l}\text { Classification based on } \\
\text { ISCED }\end{array}$ \\
\hline Austria $^{(26,27)}$ & $\begin{array}{l}\text { Compulsory education } \\
\text { Apprenticeship } \\
\text { Intermediate vocational school } \\
\text { Secondary school certificate } \\
\text { Secondary school certificate, nursing school } \\
\text { University degree }\end{array}$ & $\begin{array}{l}\text { Low } \\
\text { Middle }\end{array}$ \\
\hline \multirow{3}{*}{$\begin{array}{l}\text { Belgium } \\
\text { Bulgaria*(28,29) }\end{array}$} & No data by maternal education & \\
\hline & $\begin{array}{l}\text { No education } \\
\text { Primary } \\
\text { Elementary }\end{array}$ & Low \\
\hline & Secondary & Middle \\
\hline \multirow[t]{2}{*}{ Croatia $^{(30,31)}$} & Primary school & Low \\
\hline & $\begin{array}{l}\text { Secondary school } \\
\text { Higher education }\end{array}$ & $\begin{array}{l}\text { Middle } \\
\text { High }\end{array}$ \\
\hline Cyprus & No data by maternal education & \\
\hline \multirow{5}{*}{ Denmark $^{(32-34)}$} & No data by maternal education & \\
\hline & Primary school & Low \\
\hline & Vocational education & Middle \\
\hline & General or vocational upper secondary education & \\
\hline & $\begin{array}{l}\text { Short or intermediate higher education } \\
\text { Long higher education }\end{array}$ & High \\
\hline Estonia & No data by maternal education & \\
\hline \multirow{3}{*}{ Finland $^{(35,36)}$} & Basic & Low \\
\hline & Upper secondary level & Middle \\
\hline & $\begin{array}{l}\text { Lower university degree or lowest level of tertiary education } \\
\text { Highest university degree or postgraduate education }\end{array}$ & High \\
\hline \multirow[t]{3}{*}{ France ${ }^{(37,38)}$} & Less than Baccalauréat level & Low \\
\hline & Baccalauréat level & Middle \\
\hline & Above Baccalauréat level & High \\
\hline \multirow[t]{3}{*}{ Germany $^{(39)}$} & Low & Low \\
\hline & Medium & Middle \\
\hline & High & High \\
\hline \multirow[t]{7}{*}{ Greece $^{(40,41)}$} & No school at all & Low \\
\hline & Some primary classes & \\
\hline & Primary school graduate & \\
\hline & Third high school class & Middle \\
\hline & High school graduate & \\
\hline & Graduate technological education institutions (TEI) & High \\
\hline & University graduate & \\
\hline \multirow{5}{*}{$\begin{array}{l}\text { Hungary } \\
\text { Ireland }\end{array}$} & No data by maternal education & \\
\hline & Lower secondary or less & Low \\
\hline & Leaving certificate & Middle \\
\hline & Sub-degree & \\
\hline & Degree or third level & High \\
\hline \multirow{3}{*}{ Italy $(44,45)$} & Compulsory education & Low \\
\hline & Diploma & Middle \\
\hline & Graduation & High \\
\hline \multirow[t]{4}{*}{ Latvia (I Pudule, unpublished results) ${ }^{(46)}$} & Elementary & Low \\
\hline & Secondary & Middle \\
\hline & Vocational education & \\
\hline & Higher education & High \\
\hline Lithuania & No data by maternal education & \\
\hline \multirow[t]{3}{*}{ Luxembourg $^{(47,48)}$} & Primary school education or less & Low \\
\hline & Professional education & Middle \\
\hline & Secondary or higher education & High \\
\hline \multirow[t]{3}{*}{ Malta $^{(49,50)}$} & Primary and secondary education & Low \\
\hline & Post-secondary and non-tertiary education & Middle \\
\hline & Tertiary education & High \\
\hline \multirow{3}{*}{ Netherlands ${ }^{(51,52)}$} & Low & Low \\
\hline & Middle & Middle \\
\hline & High & High \\
\hline \multirow[t]{3}{*}{ Poland (M Kostuch, unpublished results) } & Low level of education & Low \\
\hline & Middle level of education & Middle \\
\hline & High level of education & High \\
\hline Portugal & No data by maternal education & \\
\hline \multirow[t]{4}{*}{ Romania $^{(50,53)}$} & Without primary school & Low \\
\hline & With primary school & \\
\hline & Medium studies & Middle \\
\hline & Superior studies & High \\
\hline
\end{tabular}


Table 1 Continued

\begin{tabular}{|c|c|c|}
\hline Country & $\begin{array}{l}\text { Indicators used for level of maternal education in } \\
\text { national surveys or studies }\end{array}$ & $\begin{array}{l}\text { Classification based on } \\
\text { ISCED }\end{array}$ \\
\hline Slovak Republic & No data by maternal education & \\
\hline \multirow{4}{*}{$\begin{array}{l}\text { Slovenia (M Gabrijelcic, unpublished } \\
\text { results) }\end{array}$} & Lowest education & Low \\
\hline & Technical secondary education & Middle \\
\hline & Academic and professional first cycle degree (Bologna I) & High \\
\hline & University degree and more & \\
\hline \multirow[t]{3}{*}{ Sweden ${ }^{(50,55)}$} & Elementary & Low \\
\hline & Upper secondary or college $\leq 2$ years & Middle \\
\hline & College $>3$ years or qraduate & High \\
\hline \multirow[t]{3}{*}{ UK: England \& Wales ${ }^{(50,56)}$} & Aged 16 years or under when left full-time education & Low \\
\hline & Aged $17-18$ years when left full-time education & Middle \\
\hline & Aged more than 18 years when left full-time education & High \\
\hline \multirow[t]{3}{*}{ Norway ${ }^{(50,57)}$} & $\leq 12$ years of education & Low \\
\hline & $13-15$ years of education & Middle \\
\hline & $\geq 16$ years of education & High \\
\hline Iceland & No data by maternal education & \\
\hline
\end{tabular}

ISCED, International Standard Classification of Education.

*Bulgaria: only up to secondary level reported in Bulgarian study making it incomparable with other surveys.

†Luxembourg: secondary and higher education were reported together making it incomparable with other surveys.

Table 2 Any breast-feeding (ABF) rate by level of maternal education in twenty-seven EU countries plus Norway and Iceland, 2006-2016

\begin{tabular}{|c|c|c|c|c|c|c|c|c|}
\hline \multirow[b]{2}{*}{ Country, date of publication (date of data collection) } & \multicolumn{2}{|c|}{$\mathrm{ABF}(\%)$} & \multicolumn{2}{|c|}{$\begin{array}{c}\text { ABF at } \leq 2 \text { months } \\
(1-8 \text { weeks) }(\%)\end{array}$} & \multicolumn{2}{|c|}{$\begin{array}{c}\text { ABF at } \leq 4 \text { months } \\
(8-16 \text { weeks })(\%)\end{array}$} & \multicolumn{2}{|c|}{$\mathrm{ABF}$ at 6 months (\%) } \\
\hline & Mean & LMH & Mean & LMH & Mean & $\mathrm{LMH}$ & Mean & $\mathrm{LMH}$ \\
\hline Austria $2007(2006)^{(26)}$ & 93 & $\begin{array}{l}L=85 \\
M=95 \\
H=98\end{array}$ & & & 72 & & 55 & \\
\hline Belgium $2013(2012)^{(58)}$ & 75 & & & & & & & \\
\hline${\text { Bulgaria* } 2010(2007)^{(29)}}^{(29)}$ & 95 & $\begin{array}{l}L=91 \\
M=92^{*}\end{array}$ & 93 & & & & & \\
\hline Croatia $2014(2011)^{(59)}$ & 93 & & & & & & & \\
\hline Croatia $2013(2012)^{(30)}$ & & $\begin{array}{l}L=87 \\
M=93 \\
H=95\end{array}$ & & & & & & \\
\hline Cyprus $2006(2004)^{(60)}$ & 79 & & & & & & & \\
\hline Czech Republic $2009(2007)^{(61)}$ & 96 & & & & & & & \\
\hline Denmark $2016(2014)^{(32)}$ & & & 90 & & & & & \\
\hline Estonia $2016(2015)^{(62)}$ & & & 88 & & & & & \\
\hline Finland $2012(2010-2011)^{(36)}$ & & & & $\begin{array}{l}L=85 \\
M=90 \\
H=98\end{array}$ & & & & \\
\hline Finland $2009(1996-2004)^{(63)}$ & 99 & & 92 & & & & 58 & \\
\hline France $2016(2013)^{(38)}$ & 66 & $\begin{array}{l}L=55 \\
M=60 \\
H=71\end{array}$ & & & & & & \\
\hline Germany 2015 (2009-2012) ${ }^{(39)}$ & 82 & $\begin{array}{l}L=68 \\
M=85 \\
H=95\end{array}$ & & & & & & \\
\hline Greece $2009(2006-2008)^{(40)}$ & 88 & & 54 & & 39 & $\begin{array}{l}L=33 \\
M=38 \\
H=41\end{array}$ & 22 & $\begin{array}{l}L=20 \\
M=23 \\
H=24\end{array}$ \\
\hline Hungary $2014(2012)^{(64)}$ & 96 & & & & & & & \\
\hline Ireland $2010(2008-2009)^{(43)}$ & 57 & $\begin{array}{l}L=29 \\
M=54 \\
H=79\end{array}$ & & & & & & \\
\hline Italy $2014(2013)^{(45)}$ & 86 & $\begin{array}{l}L=82 \\
M=86 \\
H=89\end{array}$ & & & 42 & & & \\
\hline Latvia $2010(2010)^{(65)}$ & 88 & & & & & & & \\
\hline Lithuania $2016(2015)^{(66)}$ & & & & & 64 & & 45 & \\
\hline Luxembourg† $2010(2008)^{(47)}$ & 90 & $\begin{array}{l}L=88 \\
M=87 \\
H=93 \dagger\end{array}$ & & & 45 & & 41 & \\
\hline
\end{tabular}




\begin{tabular}{|c|c|c|c|c|c|c|c|c|}
\hline \multirow[b]{2}{*}{ Country, date of publication (date of data collection) } & \multicolumn{2}{|c|}{$\mathrm{ABF}(\%)$} & \multicolumn{2}{|c|}{$\begin{array}{l}\text { ABF at } \leq 2 \text { months } \\
(1-8 \text { weeks })(\%)\end{array}$} & \multicolumn{2}{|c|}{$\begin{array}{l}\text { ABF at } \leq 4 \text { months } \\
(8-16 \text { weeks })(\%)\end{array}$} & \multicolumn{2}{|c|}{ ABF at 6 months $(\%)$} \\
\hline & Mean & $\mathrm{LMH}$ & Mean & LMH & Mean & $\mathrm{LMH}$ & Mean & $\mathrm{LMH}$ \\
\hline Malta $2015\left(2010\right.$ \& 2012) ${ }^{(49)}$ & 71 & $\begin{array}{l}L=44 \\
M=63 \\
H=74\end{array}$ & & & & & 38 & \\
\hline Netherlands $2015(2015)^{(52)}$ & 80 & $\begin{array}{l}L=68 \\
M=81 \\
H=89\end{array}$ & & & 59 & & 52 & \\
\hline Poland 2016 (M Kostuch, unpublished results) & & $\begin{array}{l}\mathrm{L}=95 \\
\mathrm{M}=95 \\
\mathrm{H}=95\end{array}$ & & & & & & $\begin{array}{l}L=38 \\
M=47 \\
H=45\end{array}$ \\
\hline Poland $2014(2013)^{(67)}$ & 98 & & 46 & & & & & \\
\hline Portugal $2007(2003)^{(68)}$ & 91 & & & & 55 & & 34 & \\
\hline Romania $2011(2010)^{(53)}$ & 93 & & & & 71 & & 49 & \\
\hline Sloveniał $2010^{(65)}$ & 97 & & & & & & & \\
\hline Spain $2016(2011-12)^{(69)}$ & & & 66 & & 54 & & 29 & \\
\hline Sweden $2016(2004-2010)^{(55)}$ & & & & $\begin{array}{l}L=95 \\
M=96 \\
H=99\end{array}$ & & & 63 & $\begin{array}{l}L=49 \\
M=57 \\
H=79\end{array}$ \\
\hline Sweden $2015(2013)^{(70)}$ & 96 & & 86 & & & & & \\
\hline UK: England \& Wales $2012(2010)^{(56)}$ & 81 & $\begin{array}{l}\mathrm{L}=63 \\
\mathrm{M}=75 \\
\mathrm{H}=91\end{array}$ & 55 & & & & 34 & \\
\hline Norway $2010(1999-2008)^{(57)}$ & 99 & $\begin{array}{l}L=98 \\
M=99 \\
H=99\end{array}$ & 94 & & & & 80 & \\
\hline Iceland $2012(2004-2008)^{(71)}$ & 98 & & 92 & & & & 74 & \\
\hline
\end{tabular}

L, low level of education (ISCED 0-2); M, medium level of education (ISCED 3-4); H, high level of education (ISCED 5-6); ISCED, International Standard Classification of Education.

*Bulgaria: maternal education levels incomparable with other surveys.

†Luxembourg: maternal education levels incomparable with other surveys.

¥Mean duration of $A B F: L=7$ months, $M=9$ months, $H=11$ months.

\section{Statistical analysis}

All data were inserted and cleaned in MS Excel (Microsoft Office 2016). Relative breast-feeding rates with reference to high level of maternal education were computed for middle and low levels of maternal education. For statistical testing, breast-feeding percentage values in the groups by level of maternal education were converted to arcsine values to apply parametrical testing. For comparisons between multiple groups, ANOVA with the post hoc Tukey honest significant difference test was applied and $P<0.05$ was considered to indicate statistical significance. Breastfeeding cessation rates were evaluated with the matchedpair $t$ test. The statistical software package IBM SPSS Statistics version 24 was used for statistical testing.

\section{Results}

The levels of maternal education reported are listed in Table $1^{(26-57)}$. No breast-feeding rates by level of education were found for one-third ( $n$ 10) of the countries (Belgium, Cyprus, Czech Republic, Estonia, Hungary,
Lithuania, Portugal, Slovak Republic, Spain and Iceland). The levels of mothers' education were grouped into high, medium or low categories using the ISCED classification for those twenty countries that did report breast-feeding rates by level of education. Only eighteen countries could be compared based on the ISCED classification since education levels in Bulgaria and Luxembourg could not be matched to the ISCED classification. Bulgaria's and Luxembourg's highest level of education included 'secondary' or 'secondary or higher', respectively, whereas the ISCED levels 5-6 (i.e. high) include only tertiary education plus bachelor or equivalent and higher but not secondary.

\section{Any breast-feeding}

Data on average rates of ABF were found for all except one country (Slovak Republic; Table 2(26,29,30,32,36,38-40, $43,45,47,49,52,53,55-71)$ ). The dates when $\mathrm{ABF}$ rates were published ranged from 2006 to 2016: the oldest in Cyprus in 2006; Austria and Portugal in 2007; Greece in 2009; six countries (Bulgaria, Latvia, Ireland, Luxembourg, Slovenia 
Table 3 Exclusive breast-feeding (EBF) rate by level of maternal education in twenty-three EU countries plus Norway and Iceland, 2006-2016

\begin{tabular}{|c|c|c|c|c|c|c|c|c|}
\hline \multirow[b]{2}{*}{ Country, date of publication (date of data collection) } & \multicolumn{2}{|c|}{$\begin{array}{l}\text { EBF at } \leq 1 \text { month } \\
(1-4 \text { weeks })(\%)\end{array}$} & \multicolumn{2}{|c|}{$\begin{array}{l}\text { EBF at } \leq 3 \text { months } \\
(5-12 \text { weeks })(\%)\end{array}$} & \multicolumn{2}{|c|}{ EBF at 4 months (\%) } & \multicolumn{2}{|c|}{ EBF at 6 months $(\%)$} \\
\hline & Mean & $\mathrm{LMH}$ & Mean & LMH & Mean & $\mathrm{LMH}$ & Mean & $\mathrm{LMH}$ \\
\hline Austria $2007(2006)^{(26)}$ & & & 60 & & & & 10 & \\
\hline Belgium $2013(2012)^{(58)}$ & & & 28 & & & & 8 & \\
\hline Croatia 2014 (2011) & & & 76 & & & & 15 & \\
\hline Croatia $2013(2012)^{(30)}$ & & & & & 38 & $\begin{array}{l}L=25 \\
M=32 \\
H=38\end{array}$ & & \\
\hline Cyprus $2006(2004)^{(60)}$ & & & 52 & & 15 & & 12 & \\
\hline Czech Republic 2011 (2009) $^{(72)}$ & & & 35 & & & & 18 & \\
\hline Denmark $2016(2014)^{(32)}$ & 79 & & 69 & & 61 & $\begin{array}{l}L=39 \\
M=54 \\
H=71\end{array}$ & 17 & \\
\hline Estonia $2016(2015)^{(62)}$ & 80 & & 64 & & & & 30 & \\
\hline Finland $2012(2010-2011)^{\star(36)}$ & & & & & 23 & & 6 & \\
\hline Finland $2009(1996-2004)^{(63)}$ & 56 & & 32 & & & & & \\
\hline France $2016(2013)^{(38)}$ & & & & & 30 & & & \\
\hline France $2013(2003-2006)^{(73)}$ & & & 40 & & & $\begin{array}{l}L=16 \\
M=20 \\
H=22\end{array}$ & 18 & \\
\hline Germany 2015 (2009-2012) $)^{(39)}$ & & & & & 34 & $\begin{array}{l}L=20 \\
M=35 \\
H=50\end{array}$ & & \\
\hline Greece $2009(2006-2008)^{(40)}$ & 21 & $\begin{array}{l}L=17 \\
M=15 \\
H=25\end{array}$ & 10 & & 8 & & 0.5 & \\
\hline Hungary $2014(2012)^{(64)}$ & & & & & 62 & & & \\
\hline Hungary $2009(2007)^{(61)}$ & & & 95 & & & & 44 & \\
\hline Italy $2014(2013)^{(45)}$ & 49 & & 44 & & 39 & & 6 & \\
\hline Latvia 2016 (2006) (I Pudule, unpublished results) & 92 & & 63 & & 53 & & 34 & $\begin{array}{l}L=12 \\
M=24 \\
H=38\end{array}$ \\
\hline Lithuania $2016(2015)^{(66)}$ & & & & & & & 31 & \\
\hline Luxembourg† $2010(2008)^{(47)}$ & & & & & $26 \dagger$ & $\begin{array}{l}L=18 \\
M=16 \\
H=32\end{array}$ & 6 & $\begin{array}{l}L=6 \\
M=6 \\
H=7 \dagger\end{array}$ \\
\hline Netherlands $2015(2015)^{(52)}$ & 57 & $\begin{array}{l}L=50 \\
M=58 \\
H=65\end{array}$ & 47 & $\begin{array}{l}L=42 \\
M=46 \\
H=54\end{array}$ & 45 & $\begin{array}{l}\mathrm{L}=40 \\
\mathrm{M}=45 \\
\mathrm{H}=52\end{array}$ & 39 & \\
\hline Poland $2014(2013)^{(67)}$ & & & & & 29 & & 9 & $\begin{array}{l}L=6 \\
M=10 \\
H=10\end{array}$ \\
\hline Portugal 2007 (2003) & & & 40 & & & & 17 & \\
\hline Romania $2011(2010)^{(53)}$ & 56 & & 50 & & 25 & & 13 & $\begin{array}{l}L=14 \\
M=12 \\
H=15\end{array}$ \\
\hline Slovak Republic $2011(2010)^{(74)}$ & 90 & & 73 & & 64 & & 49 & \\
\hline Sweden $2015(2013)^{(70)}$ & 83 & & 67 & & 53 & & 15 & \\
\hline UK: England \& Wales $2012(2010)^{(56)}$ & 30 & & 17 & & 12 & & 1 & \\
\hline Norway 2010 (1999-2008) & 85 & & 71 & & 44 & & 2 & \\
\hline Iceland $2012(2004-2008)^{(71)}$ & 86 & & 67 & & 50 & & 8 & \\
\hline
\end{tabular}

L, low level of education (ISCED 0-2); M, medium level of education (ISCED 3-4); H, high level of education (ISCED 5-6); ISCED, International Standard Classification of Education.

*Median duration of EBF: $L=1$ month, $M=1.4$ months, $H=2$ months.

†Luxembourg: maternal education levels incomparable with other surveys.

and Norway) in 2010; three countries (Czech Republic, Romania and Slovak Republic) in 2011; three countries (Finland, UK and Iceland) in 2012; Belgium in 2013; three countries (Croatia, Hungary and Italy) in 2014; three countries (Germany, Malta and Netherlands) in 2015; and seven countries (Denmark, Estonia, France, Lithuania, Poland, Spain and Sweden) in 2016. In addition to the wide time span between the dates of publication, each country also used different time frames and variables for reporting their $\mathrm{ABF}$ rates. The time frames ranged from infant ever breast-fed, initiation at birth, within the first hour, at discharge and from breast-feeding at a range of weeks and/or months, up to 6 months. This resulted in about seventy different variables for ABF. In an attempt to compare the wide range of time frames they were grouped into four: any breast-feeding (ABF); $\mathrm{ABF}$ at $\leq 2$ months (18 weeks); $\mathrm{ABF}$ at $\leq 4$ months (8-16 weeks); and $\mathrm{ABF}$ at 6 months (Table 2). 
Average ABF rates above $90 \%$ were found in thirteen countries: Finland (99\%), Norway (99\%), Iceland (98\%) Poland (98\%), Slovenia (97\%), Czech Republic (96\%), Hungary (96\%), Sweden (96\%), Bulgaria (95\%), Austria (93\%), Croatia (93\%), Romania (93\%) and Portugal (91\%; Table 2). Average ABF rates between 80 and $90 \%$ were found in seven countries: Luxembourg (90\%), Greece and Latvia (88\%), Italy (86\%), Germany (82\%), UK (81\%) and Netherlands (80\%). Average ABF rates between 70 and $80 \%$ were found in three countries: Cyprus (79\%), Belgium (75\%) and Malta (71\%). The lowest rates of $\mathrm{ABF}$ were found in France and Ireland, 66 and 57\%, respectively. Average $\mathrm{ABF}$ rates at $\leq 2$ months were highest (>80\%) in Nordic countries, Estonia and Bulgaria: Norway (94\%), Bulgaria (93\%), Iceland (92\%), Finland (92\%), Denmark (90\%), Estonia (88\%) and Sweden (86\%). Average ABF rates above $50 \%$ at 4 months were found in six countries: Austria ( $72 \%)$, Romania ( $71 \%$ ), Lithuania (64\%), Netherlands (59\%), Portugal (55\%) and Spain (54\%); and average ABF rates below $50 \%$ at 4 months in Poland (46\%), Greece (39\%), Luxembourg (45\%) and Italy ( $42 \%)$. Average ABF rates at 6 months were reported by fourteen countries, where only Nordic countries, Austria and the Netherlands reported rates above $50 \%$ : Norway (80\%), Iceland (74\%), Sweden (63\%), Finland (58\%), Austria (55\%) and Netherlands (52\%). The lowest ABF rates at 6 months were reported in the UK and Mediterranean countries: Malta (38\%), UK (34\%), Portugal (34\%), Spain (29\%) and Greece (22\%).

\section{Any breast-feeding disparities}

Fifteen countries reported rates of ABF disaggregated by education level but the data from Bulgaria and Luxembourg could not be compared with the others. Among the thirteen countries that were compared, there is a significant difference in $\mathrm{ABF}$ rates between mothers with high, medium and low education levels. The proportion of mothers with high education levels, practising $\mathrm{ABF}$, is on average $20 \%$ higher $(P=0.035)$ than those with low levels. Figure 1 illustrates a clear tendency towards a social gradient in breast-feeding rates between the mothers according to high, middle and low level of education. However, some countries have less steep social gradients as shown by the very small percentage inequality gaps in the Polish, Norwegian and Swedish mothers with high and low education levels (Fig. 2). In Poland, Norway and Sweden, more than $90 \%$ of mothers are breast-feeding regardless of their level of education and so the inequality gaps are minor. Small disparities are observed in Italy and Croatia $(<10 \%)$, with relatively larger inequality gaps in Finland and Austria $(<20 \%)$ and in France, the Netherlands and Germany (<30\%). The largest inequality gaps are observed in the UK (31\%), Malta (41\%) and Ireland (63\%; Fig. 2). In five countries (Greece, Poland, Sweden, Luxembourg and Netherlands), where rates are reported at more than one time point during the first 6 months, there is a marked rapid cessation after initiation. The cessation gradient tends to be steeper in mothers with low level of education as they stop breast-feeding earlier (mean 71 (SD 17) \%), compared with those having high education level (mean 62 (sD 17) \%; $P=0.036$ ). Similarly, at 6 months, the inequality gap in $\mathrm{ABF}$ of Swedish mothers increases to $38 \%$ as more mothers with low education level stop breast-feeding earlier compared with those with higher education. Low levels of maternal education are not only associated with low rates of initiation but also with a higher probability of early cessation.

\section{Exclusive breast-feeding at 6 and 4 months}

Only six countries (Bulgaria, Germany, Ireland, Malta, Slovenia and Spain) did not report the average EBF rates at 6 months (Table $3^{(26,30,32,36,38-40,45,47,52,53,56-64,66-68,70-74)}$ ). At 6 months, the highest average EBF rates were reported in Slovakia (49\%) and Hungary (44\%) and the lowest in the UK (1\%) and Greece (0.5\%; Table 3). The WHO recommendation to Member States used to be to collect national data on EBF rates at 4 months, but in the year 2000 this recommendation was increased to 6 months. However, many countries continue to collect data on EBF rates at 4 months (Table 3 ). The highest average rates of EBF at 4 months ( $\geq 50 \%)$ were observed in six countries: Slovak Republic, Hungary and Denmark (64, 62 and 61\%, respectively) followed by Sweden, Latvia and Iceland (53, 53 and $50 \%$, respectively). The lowest average $\mathrm{EBF}$ rates at 4 months $(<20 \%)$ were in Cyprus, the UK and Greece (15, 12 and $8 \%$, respectively).

\section{Exclusive breast-feeding disparities at 6 and 4 months}

Only four countries, Latvia, Luxembourg, Poland and Romania, reported rates of EBF at 6 months by level of maternal education (Table 3). In Poland and Latvia, two to three times more mothers with high compared with low education level practised EBF at 6 months. In both Romania and Luxembourg there was little difference in EBF rates at 6 months between mothers with high compared with low education level (Table 3). Six countries reported EBF rates at 4 months by level of maternal education (Table 3): more Danish and German mothers with high compared with low education level practised EBF and the inequality gaps were 45 and $60 \%$, respectively. Similarly, a greater proportion of Dutch, French, Croatian and Luxembourg mothers with high compared with low education level practised EBF at 4 months and the respective inequality gaps were 23, 27, 34 and $44 \%$ at 4 months.

Finally, Table 4 lists the wide range of different time frames used to define breast-feeding rates, for example: initiation of breast-feeding at birth; initiation of breast-feeding within the first hour; any breast-feeding; ever breast-feeding; breast-feeding at discharge from hospital; breast-feeding at 


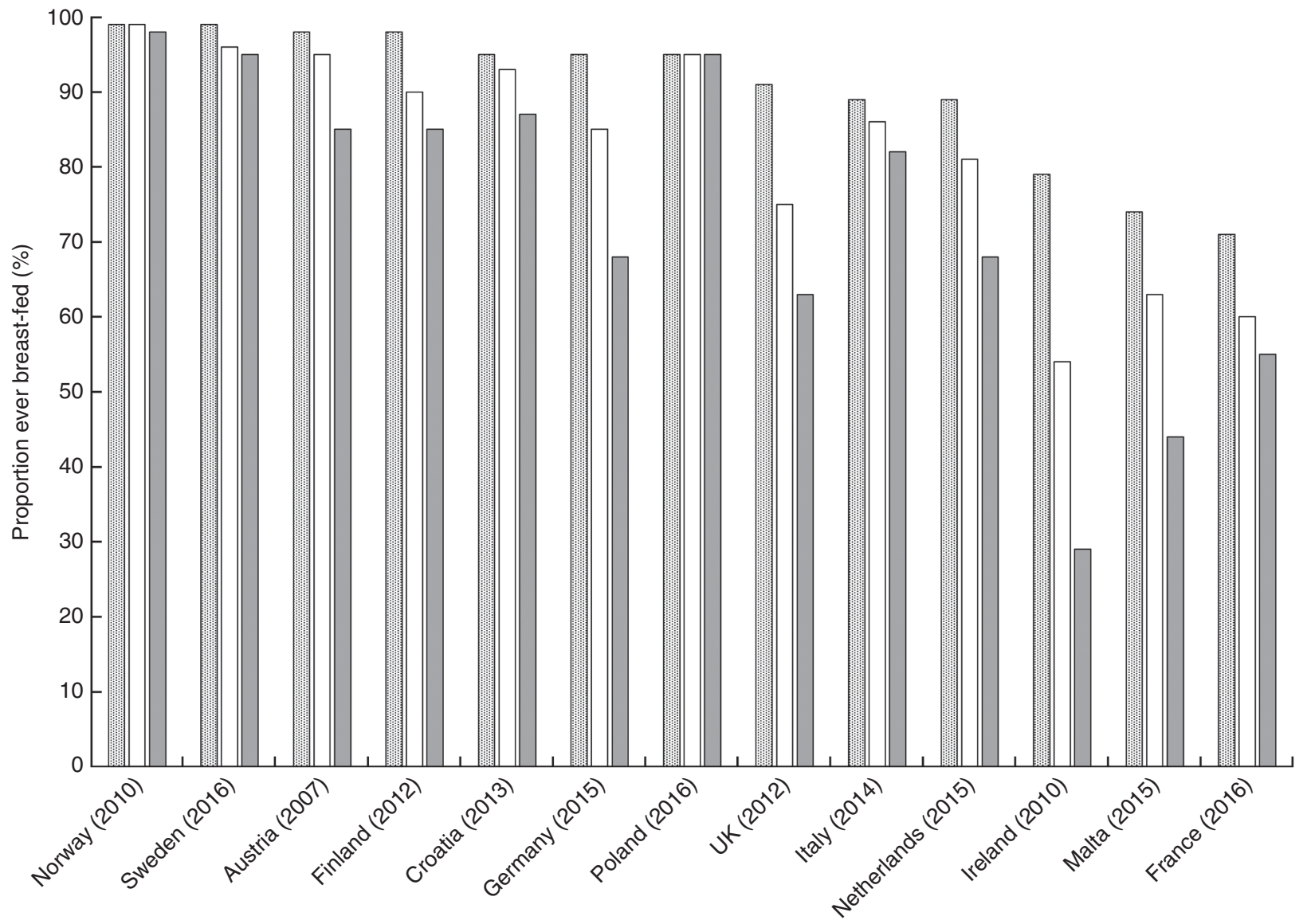

Fig. 1 Any breast-feeding rate according to high (國), middle ( $\square$ ) and low ( $\square$ ) maternal education levels in twelve EU countries plus Norway, 2006-2016

1 week; and breast-feeding at or less than $1,2,3$ and 4 months. This wide range of non-standardized time frames makes comparison between countries impractical.

\section{Discussion}

The current paper presents information comparing the rates of breast-feeding in Europe in mothers of different SES, defined by level of maternal education. The results confirm what other authors have stressed concerning the need for standardized methods to monitor breast-feeding rates in Europe to allow comparison between countries and recommendations to reduce inequalities ${ }^{(75,76)}$.

\section{Any breast-feeding and disparities}

The results confirm previous studies and provide new comparative evidence that disparities exist, not only within but also between countries ${ }^{(6,77)}$. As indicated, based on surveys from thirteen countries, one-fifth more mothers with high compared with low education level breast-fed. Whereas the initial disparities in the Nordic, Baltic and Central European countries are relatively small, the inequality gaps found in Ireland, Malta, the UK, Germany, the Netherlands and France are high and should give cause for concern to the respective governments (Fig. 2). When breast-feeding rates are reported only as national averages, these average figures can conceal a steep gradient between mothers with high compared with low education level. For example McAndrew et al. ${ }^{(56)}$ found that the incidence of $\mathrm{ABF}$ was $91 \%$ among UK mothers with high education level compared with 63\% among those with low education level. Similarly, five countries (Greece, Poland, Sweden, Luxembourg and Netherlands) reported rates over two or three time periods during which the trend is that the inequality gaps get wider. Even Nordic countries, for example Sweden, report that by 6 months the inequality gap increases considerably as more Swedish mothers with low education stop breast-feeding earlier than those with higher education. This is confirmed by Wallby and Hjern ${ }^{(78)}$, who found that low income levels are a strong predictor for early cessation of breast-feeding and recommended extra protection for low-income Swedish mothers. Similarly Finnish ${ }^{(10,79,80)}$ and Danish studies ${ }^{(81)}$ reported that mothers with low compared with high education were more likely to introduce foods too early. Indeed, even Norwegian authors recently reported that very few (7\%) Norwegian mothers with low education level still exclusively breast-fed by 5 months compared with three times more mothers $(22 \%)$ with high level ${ }^{(82)}$. 


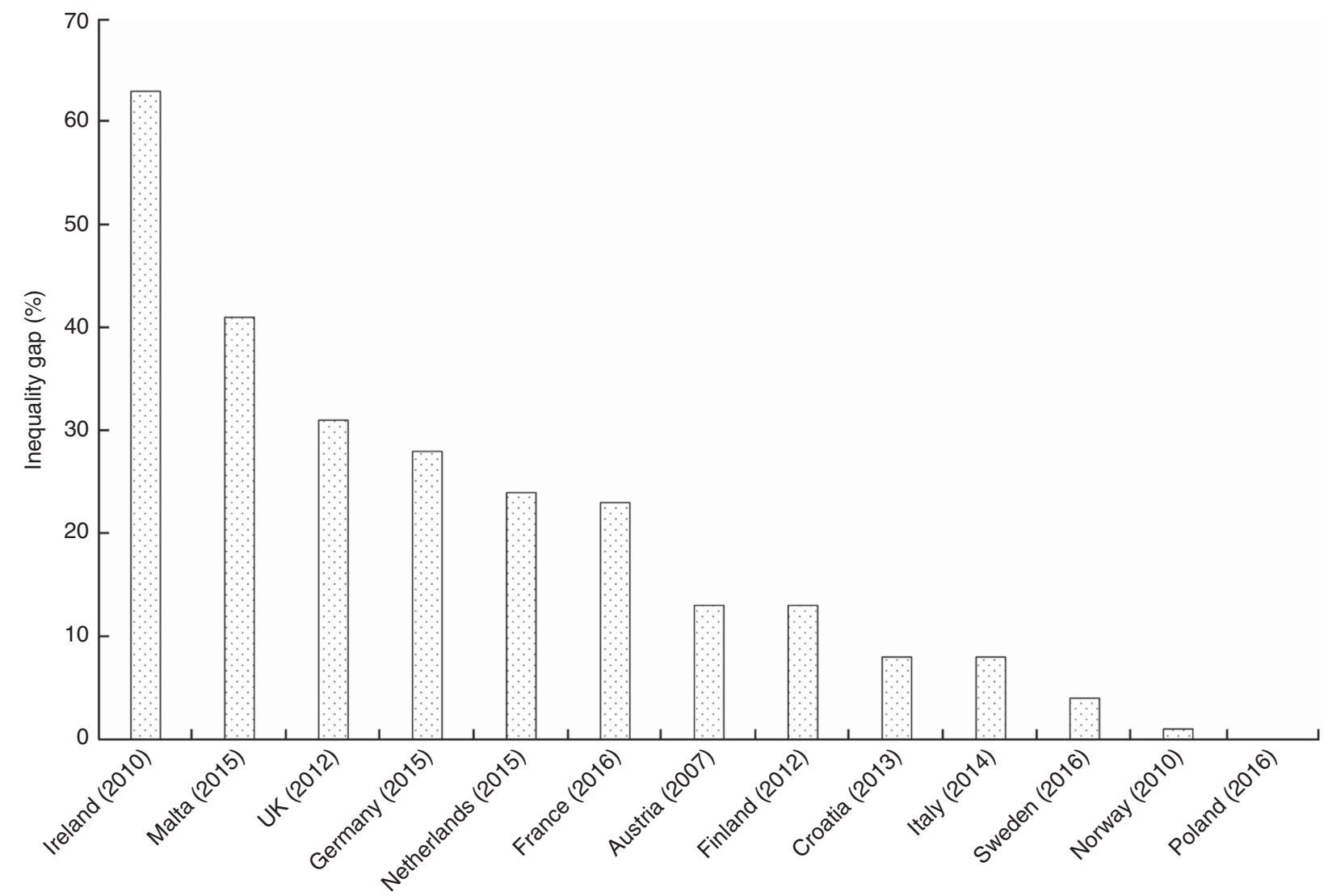

Fig. 2 Inequality gap in any breast-feeding rate between maternal high compared with low education level in twelve EU countries plus Norway, 2006-2016. Inequality gap $(\%)=[$ (proportion of breast-feeding mothers with high level of education - proportion of breast-feeding mothers with low level of education)/proportion of breast-feeding mothers with high level of education] $\times 100$

Table 4 Different breast-feeding time frames used within the thirty European countries

\begin{tabular}{lccr}
\hline Time frame & $\begin{array}{c}\text { Number of } \\
\text { countries }\end{array}$ & $\begin{array}{c}\text { Disaggregated by maternal } \\
\text { education }\end{array}$ & $\begin{array}{c}\text { Breast-feeding rate (\%), } \\
\text { minimum-maximum }\end{array}$ \\
\hline Infant ever breast-fed & 25 & 13 & $57-99$ \\
Breastfeeding within the first hour or at birth & 6 & 0 & $5-93$ \\
Breast-feeding at discharge & 3 & 0 & $58-88$ \\
ABF at $<2$ months (from 1 up to 8 weeks) & 11 & 2 & $46-94$ \\
ABF at $\leq 4$ months (from 9 up to 16 weeks) & 9 & 1 & $39-72$ \\
ABF at 6 months & 14 & 3 & $22-80$ \\
ABF at 1 year & 8 & 0 & $8-27$ \\
EBF at $\leq 1$ month (from 1 up to 4 weeks) & 13 & 2 & $21-92$ \\
EBF at $\leq 3$ months (from 5 up to 12 weeks) & 21 & 1 & $10-95$ \\
EBF at/up to/until 4 months (from 12 up to & 19 & 6 & $8-64$ \\
16 weeks) & 24 & 4 & $0.5-49$ \\
EBF at/up to/until 6 months (from 16 up to & & & \\
24 weeks/6 months) & & & \\
\hline
\end{tabular}

$\mathrm{ABF}$, any breast-feeding; EBF, exclusive breast-feeding.

${ }^{*} \mathrm{WHO}$ recommendations changed from 4 months of EBF to 6 months of EBF in 2000.

\section{Exclusive breast-feeding and disparities}

The results confirm that on average the EBF rates in most countries, except the Slovak Republic (49\%) and Hungary (44\%), are well below governments' 2025 target of at least $50 \% \mathrm{EBF}$ at 6 months $^{(1)}$. Victora et $a l^{(2)}$ confirm that Nordic countries have high breast-feeding initiation rates of over $90 \%$. Similarly, Baltic countries and those in Central Europe report high initiation rates, with over $90 \%$ in Bulgaria, Croatia, Czech Republic, Hungary, Poland, Slovak Republic and Slovenia. Even at 6 months about one-third of Baltic (Latvian, Lithuanian and Estonian) mothers are still practising EBF (Table 3). Results from smaller studies ${ }^{(83,84)}$ report that, on average, about onehalf of Lithuanian mothers exclusively breast-feed for 6 months, but only one-fifth with low compared with fourfifths of those with high level of education continue until 
6 months. Slovakia and Hungary, along with the Baltic and Nordic countries, report the highest EBF rates (Table 3) and interestingly these countries provide the best statutory entitlement of paid parental leave, closely followed by Czech Republic and Bulgaria ${ }^{(85)}$. In contrast, French mothers can only expect 6 weeks off work before and 10 weeks after birth, and even those with high education level have one of the lowest breast-feeding initiation rates (71\%) in Europe (although dramatically increased since $1995)^{(86,87)}$. Parental leave payment rates are also low in Ireland and the UK, where fully paid maternity leave lasts only 9 and 12 weeks, respectively ${ }^{(85)}$. Furthermore it appears that French, Irish and British mothers are subjected to aggressive marketing and many violations are reported against the International Code of Marketing of Breast Milk Substitutes ('the Code' hereafter) in France ${ }^{(88)}$, Ireland ${ }^{(89)}$ and the $\mathrm{UK}^{(90)}$. Robust policies, better maternity leave and protection against marketing are needed not only to achieve the global target of at least $50 \% \mathrm{EBF}$ in the first 6 months by $2025^{(1)}$ but also to achieve the EU Council's aim $^{(91)}$ to halt the rise in childhood obesity, which is closely associated to poor infant feeding practices. For example, parents have the right to receive information on infant feeding practices, from health professionals, that is independent of commercial interests and free from conflicts of interest. Low levels of breast-feeding have been attributed to lack of knowledge about breastfeeding and incorrect advice on infant feeding from health professionals in Lithuania ${ }^{(92)}$, Malta ${ }^{(93)}$ and Romania ${ }^{(94)}$.

\section{Implications for public bealth policy}

A recent German study ${ }^{(95)}$ is among the first to demonstrate a widening socio-economic disparity in breastfeeding practices using a time-trend analysis. This disparity was largely explained by the proportion of German mothers with low SES who were likely to be obese and/or to smoke. Both these risk factors are well known to be associated with low breast-feeding rates ${ }^{(96,97)}$. Breastfeeding cessation among Dutch mothers with low education level also increases rapidly ${ }^{(98)}$ and so in the Netherlands there is increased focus on how to reduce health inequalities in pregnant women and their offspring ${ }^{(99)}$. Similar calls are being made in Italy, where authors stress the need for policies that specifically support mothers with low level of education ${ }^{(100,101)}$. In the future it is crucial to carry out regular monitoring of trends of breast-feeding rates along with the relative prevalence of obesity. The latest data (2015-2017) from the WHO Childhood Obesity Surveillance Initiative ${ }^{(102)}$ show that Southern European countries have the highest rate of child obesity. In Cyprus, Greece, Italy, Malta and Spain, approximately one in five boys is obese, whereas Nordic and Baltic countries are among the countries with the lowest rates. Obesity in young children is associated with low initiation rates of breast-feeding along with early cessation $^{(103,104)}$. This both negatively affects long-term health and increases the risk of obesity over the next generations $^{(105)}$. However, data on both national breast-feeding rates and obesity prevalence, disaggregated by level of maternal education, are needed to better investigate the complex relationship between obesity, breast-feeding and SES. A recent review ${ }^{(106)}$ tried to separate independent outcomes but a clearer understanding of the several different mechanisms involved, and their interrelationships, is of utmost importance. The European Blueprint for Action on Breast-feeding ${ }^{(75)}$ especially recommends: full implementation of the Code and subsequent relevant World Health Assembly resolutions; maternity protection legislation that enables all working mothers to exclusively breastfeed their infants for 6 months; establishing standards for best practice within public places as well as in all maternity and childcare services; and harmonized collection, at least every 3-5 years, of disaggregated breast-feeding data that correspond to the recommended standardized indicators and definitions.

\section{Limitations}

As these comparisons are derived from data gathered using different methods over different time periods, reported rates and their comparison should be treated with caution ${ }^{(107)}$. Breast-feeding rates were collected on different dates over a long time period and a wide range of methods was used in different countries to collect breast-feeding rates (Table 4). It was attempted to harmonize education levels into three categories according to the ISCED ${ }^{(108)}$; however, our categorizations could be flawed. Furthermore, reported breastfeeding rates were not always nationally representative and so comparisons should be interpreted with caution. The inequality gap analyses are useful but limited in that they only reflect the difference between low level of maternal education compared with high. The analysis can be potentially affected by extreme values for each of these groups and does not necessarily reflect the experience of the entire population due to the different distribution of mothers' education levels ${ }^{(109)}$.

\section{Conclusion}

Overall, there is less initiation of breast-feeding and shorter duration of EBF by mothers with low compared with high education level. These findings can help governments to investigate why these disparities exist and why some countries such as the Nordic, Baltic and Central European countries have higher breast-feeding rates and lower disparities compared with other European countries. National policies common to Nordic, Baltic and Central European countries are that they have paid maternity leave regulations which go beyond the minimum stipulated by EU law. In addition, Nordic countries have been efficient in minimizing violations of the Code 
and until recently Baltic and Central European countries have not been as exposed to high levels of marketing by companies selling breast milk substitutes. The results highlight disparities in breast-feeding which can only be reduced if governments develop harmonized monitoring systems that are carried out regularly and where the data are disaggregated by SES to develop appropriate health promotion policies.

\section{Acknowledgements}

Acknowledgements: The authors acknowledge the support of the Baby Friendly Hospital Initiative (BFHI) coordinators listed as follows by country. Austria: Dr Christina Wieczorek (Austrian Public Health Institute). Croatia: Anita Pavicic Bosnjak, MD, PhD (University Hospital Sveti Duh Zagreb). Czech Republic: Zuzana Derflerová Brázdová, DrSc (Department of Public Health, Faculty of Medicine, Masaryk University). Denmark: Annette Poulsen and Christine Brot. Estonia: Ada Vahtrik (BFHI Country Coordinator). France: Dr Claire Laurent (Coordinatrice médicale IHAB France), Dr Marie-Claude Marchand, Kristina Löfgren and Caroline Francois. Germany: Heike BrulandSaal (Assistant Executive Director, Association for Support of the WHO/UNICEF BFHI). Ireland: Dr Genevieve Becker, PhD, IBCLC, MINDI (National Coordinator of the BFHI in Ireland). Latvia: Iveta Pudule (Senior Public Health Analyst, Department of Research and Health Statistics, Centre for Disease Prevention and Control). Lithuania: Daiva Šniukaitè-Adner, MSN, RN, IBCLC (BFHI National Coordinator, NBC Vice Chair). Luxembourg: Maryse Arendt (National Coordinator, Initiativ Liewensufank/UNICEF Lux). Netherlands: Mary Steen, IBCLC (Policy Maker, BFHI the Netherlands) and Caroline Kruger. Poland: Marzena Kostuch, MD, PhD. Slovenia: Mojca Gabrijelcic. UK: Anne Woods (Deputy Programme Director, Baby Friendly Initiative). Financial support: This work was carried out under a 'Pilot project related to reducing health inequalities: building expertise and evaluation of actions' (tender number SANTE/2014/C4/032; service contract number 2015-C4-03 (SI2.724119)), funded by the European Commission, DG Health and Food Safety, Unit C-4 Health Determinants and Inequalities. The European Commission, DG Health and Food Safety, Unit C-4 Health Determinants and Inequalities had no role in the design, analysis or writing of this article. The information and views set out in this publication are those of the authors and do not necessarily reflect the official opinion of the Commission. The Commission does not guarantee the accuracy of the data included in this publication. Neither the Commission nor any person acting on the Commission's behalf may be held responsible for use which may be made of the information contained herein. Conflict of interest: None. Authorship: M.S. collected and analysed data, wrote the initial version of the manuscript and contributed to the final version. A.P. supported statistical analysis, contributed to the preparation of the manuscript and provided critical comments. A.R. supervised the data collection, its analysis and the writing of the manuscript, and was responsible for contacting experts on breastfeeding policy in the countries investigated. All authors reviewed and approved the manuscript. Ethics of human subject participation: Not applicable.

\section{References}

1. World Health Organization (2014) Global Nutrition Targets 2025: Breastfeeding Policy Brief. Geneva: WHO; available at http://www.who.int/nutrition/topics/global targets_breastfeeding_policybrief.pdf

2. Victora CG, Bahl R, Barros AJ et al. (2016) Breastfeeding in the 21st century: epidemiology, mechanisms, and lifelong effect. Lancet 387, 475-490.

3. Cattaneo A (2012) Academy of breastfeeding medicine founder's lecture 2011: inequalities and inequities in breastfeeding: an international perspective. Breastfeed Med 7, 3-9.

4. Brown AE, Raynor P, Benton D et al. (2009) Indices of Multiple Deprivation predict breastfeeding duration in England and Wales. Eur J Public Health 20, 231-235.

5. Ibanez G, de Reynal de Saint Michel C, Denantes M et al. (2012) Systematic review and meta-analysis of randomized controlled trials evaluating primary care-based interventions to promote breastfeeding in low-income women. Fam Pract 29, 245-254.

6. Ibanez G, Martin N, Denantes M et al. (2012) Prevalence of breastfeeding in industrialized countries. Rev Epidemiol Sante Publique 60, 305-320.

7. Kronborg H \& Vxeth M (2004) The influence of psychosocial factors on the duration of breastfeeding. Scand J SOC Med 32, 210-216.

8. Gibbs B G \& Forste R (2014) Socioeconomic status, infant feeding practices and early childhood obesity. Pediatr Obes 9, 135-146.

9. Daniels L, Mallan K M, Fildes A et al. (2015) The timing of solid introduction in an 'obesogenic' environment: a narrative review of the evidence and methodological issues. Aust N Z J Public Health 39, 366-373.

10. Erkkola M, Salmenhaara M, Nwaru BI et al. (2013) Sociodemographic determinants of early weaning: a Finnish birth cohort study in infants with human leucocyte antigen-conferred susceptibility to type 1 diabetes. Public Health Nutr 16, 296-304.

11. Mäkelä J, Vaarno J, Kaljonen A et al. (2014) Maternal overweight impacts infant feeding patterns - the STEPS Study. Eur J Clin Nutr 68, 43-49.

12. Robertson A \& Loring B (2014) Obesity and inequities. Guidance for addressing inequities in overweight and obesity. http://www.euro.who.int/_data/assets/pdf_file/ 0003/247638/obesity-090514.pdf (accessed May 2018).

13. Verret-Chalifour J, Giguère Y, Forest J-C et al. (2015) Breastfeeding initiation: impact of obesity in a large Canadian perinatal cohort study. PLoS One 10, e0117512.

14. Rasmussen K M \& Kjolhede C L (2004) Prepregnant overweight and obesity diminish the prolactin response to suckling in the first week postpartum. Pediatrics 113, e465-e471.

15. Turcksin R, Bel S, Galjaard S et al. (2014) Maternal obesity and breastfeeding intention, initiation, intensity and duration: a systematic review. Matern Child Nutr 10, 166-183. 
16. Robertson A (2015) Breastfeeding initiation at birth can help reduce health inequalities. http://www.euro.who.int/ __data/assets/pdf_file/0005/277736/Breastfeeding-initia tion-at-birth-can-help-reduce-health-inequalities.pdf?ua=1 (accessed May 2018).

17. Hoffmann R, Eikemo T A, Kulhánová I et al. (2015) Obesity and the potential reduction of social inequalities in mortality: evidence from 21 European populations. Eur J Public Health 25, 849-856.

18. Leahy-Warren P, Mulcahy H, Phelan A et al. (2014) Factors influencing initiation and duration of breast feeding in Ireland. Midwifery 30, 345-352.

19. Cattaneo A, Yngve A, Koletzko B et al. (2005) Protection, promotion and support of breast-feeding in Europe: cur rent situation. Public Health Nutr 8, 39-46.

20. Robertson A \& Schumann NL (2014) Diet, nutrition and obesity: infant feeding (breastfeeding and complimentary feeding) by socioeconomic status. http://www.healthinequalities.eu/wp-content/uploads/2016/05/Task-3-InfantFeeding-By-SES.pdf (accessed May 2018).

21. Heck KE, Braveman P, Cubbin C et al. (2006) Socioeconomic status and breastfeeding initiation among California mothers. Public Health Rep 121, 51-59.

22. World Health Organization (2009) Baby-Friendly Hospital Initiative. Revised, updated and expanded for integrated care. http://www.who.int/nutrition/publications/infantfee ding/bfhi_trainingcourse/en/ (accessed June 2018).

23. Gadeyne S, Menvielle G, Kulhanova I et al. (2017) The turn of the gradient? Educational differences in breast cancer mortality in 18 European populations during the 2000s. Int J Cancer 141, 33-44.

24. World Health Organization (2008) Indicators for Assessing infant and Young Child Feeding Practices. Part 1: Definitions. Conclusions of a Consensus Meeting beld 6-8 November 2007 in Washington, DC, USA. Geneva: WHO; available at http://apps.who.int/iris/bitstream/handle/ 10665/43895/9789241596664_eng.pdf?sequence=1

25. World Health Organization (2013) Handbook on health inequality monitoring: with a special focus on lowand middle-income countries. http://apps.who.int/iris/ bitstre am/handle/10665/85345/9789241548632_eng.pdf? sequence=1 (accessed May 2018).

26. Esberger M (2007) Säuglingsernährung Heute 2006 (Infant nutrition 2006). http://www.bmgf.gv.at/cms/home/ attachments/2/8/5/CH1101/CMS1384785444563/langfassu ng_-_saeuglingsernaehrung_heute_-_endbericht_-_2207 07.pdf (accessed May 2018).

27. Weiß SM \& Tritscher-Archan S (2011) The Austrian education system. https://www.bic.at/downloads/en/ brftipps/0_1_bildungssystem_en.pdf (accessed May 2018).

28. National Statistical Institute (2016) Education in the Republic of Bulgaria 2016. http://www.nsi.bg/sites/ default/files/files/publications/education2016.pdf (accessed May 2018).

29. Petrova S, Rangelova L, Popivanova A et al. (2010) Current infant breastfeeding practice in Bulgaria and determinants. http://ncpha.government.bg/files/Jurnal_NCPHP_4_2010. pdf (accessed May 2018).

30. Dojčinović G \& Horvat G (2013) KAKO RODITELJI I ZAJEDNICE BRINU O DJECI NAJMLAĐE DOBI U HRVATSKOJ (How parents and community care for children in Croatia). https://www.unicef.hr/wpcontent/ uploads/2015/09/Kako_roditelji_i_zajednice_brinu_o_djeci _najmlade_dobi.pdf (accessed May 2018).

31. European Centre for the Development of Vocational Training (2015) Spotlight on VET Croatia. https://www. cedefop.europa.eu/files/8092_en.pdf (accessed May 2018).

32. Johansen A, Krogh C, Pant SW et al. (2016) Amning: Temarapport of arsrapport (Breastfeeding theme report and annual report: children born in 2014). http://www.si-folkesundhed.dk/upload/temarapport_amn ing_og_årsrap port_børn_født_i_2014.pdf (accessed May 2018).

33. Pont B, Figueroa DT, Albiser E et al. (2014) Education Policy Outlook: Denmark. http://www.oecd.org/educa tion/EDUCATION\%20POLICY\%20OUTLOOK\%20DENMA RK_EN.pdf (accessed May 2018).

34. Ministry of Higher Education and Science (2016) The Danish education system. http://hfc.dk/media/252204/the_danish_ education_system_pdfa.pdf (accessed May 2018).

35. Ministry of Education and Culture (2017) Finnish education in a nutshell. http://www.oph.fi/download/146428 _Finnish_Education_in_a_Nutshell.pdf (accessed May 2018).

36. Uusitalo L, Nyberg H, Pelkonen M T et al. (2012) Imeväisikäisten ruokinta Suomessa vuonna 2010 (Infant feeding in Finland in 2010). https://thl.fi/documents/10531/95751/ Raportti\%202012\%208.pdf (accessed May 2018).

37. Population Europe Resource Finder and Archive (2017) Educational policies: France (2014). https://www.perfar. eu/policy/education/france (accessed May 2018).

38. Vilain A (2016) Deux nouveau-nés sur trois sont allaités à la naissance (Two newborns in three are breastfed). http://drees.solidarites-sante.gouv.fr/IMG/pdf/er958.pdf (accessed May 2018).

39. Robert Koch Institute (2015) Fact sheet on KiGGS Wave 1: German Health Interview and Examination Survey for Children and Adolescents - First follow-up interview 2009-2012, Germany. http://www.gbe-bund.de/pdf/Fak tenblatt_KiGGS_Welle_1_Mediennutzung_E.pdf (accessed May 2018).

40. Gaki H, Papadopoulos D, Jasmine $S$ et al. (2009) E@NIKH ME $\Lambda$ ETH $\Sigma$ YXNOTHTA $\Sigma$ KAI ПPO $\Sigma \Delta$ IOPI $\Sigma T I K \Omega N$

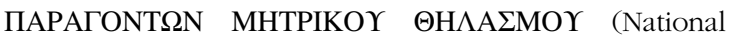
study about frequency and factors associated with breastfeeding). https://www.unicef.gr/uploads/filemana ger/PDF/info/Ekthesi_Ethnikhs_Meleths_Thilasmou.pdf (accessed June 2017)

41. Nuffic (2015) The Greek education system compared and described with the Dutch system. https://www.nuffic.nl/ en/publications/find-a-publication/education-system-greece. pdf (accessed June 2018).

42. Central Statistics Office (2011) Quarterly National Household Survey: educational attainment thematic report 2011. https://www.cso.ie/en/media/csoie/releasespublications/ documents/education/2011/educationalattainment2011. pdf (accessed May 2018).

43. Williams J, Greene S, McNally S et al. (2010) Growing up in Ireland national longitudinal study of children. The infants and their families. https://www.researchgate.net/ publication/271192227_Growing_up_in_Ireland_national _longitudinal_study_of_children_The_infants_and_their_ families (accessed May 2018).

44. Barone C \& Schizzerotto A (2006) The application of the ISCED-97 to Italy. http://www.mzes.unimannheim.de/ publications/misc/isced_97/baro08_the_application_of_ the_isced-97_to_italy.pdf (accessed May 2018).

45. ISTAT (2014) Pregnancy, childbirth, breastfeeding 2013. https://www.istat.it/it/files/2014/12/gravidanza.pdf?title= Gravidanza $\% 2 \mathrm{C}+$ parto+e+allattamento+al+seno+-+09\%2F dic\%2F2014+-+Testo+integrale.pdf (accessed May 2018).

46. Study in Latvia, Study in Europe (2017) Education system: Latvia. http://www.studyinlatvia.eu/en/studies/educationsystem (accessed May 2018).

47. Desroches S, Brochmann C, Wagener Y et al. (2010) L'alimentation de nos bébés (Feeding our babies). http:// www.sante.public.lu/fr/publications/e/etude-alba-2008-al imentation-bebes/etude-alba-2008-alimentation-bebes.pdf (accessed May 2018).

48. National Institute of Statistics (2017) International Standard Classification of Education (ISCED). http://www.statis 
tiques.public.lu/en/methodology/definitions/I/classte/ index.html (accessed May 2018).

49. Borg MB, Busuttil R \& Gauci C (2015) National Breastfeeding Policy and Action Plan 2015-2020. https://depu typrimeminister.gov.mt//en/documents/national-health-st rategies/bf_en.pdf (accessed May 2018).

50. European Commission (2014) The structure of the European education system 2014/2015: schematic diagrams. https://eacea.ec.europa.eu/sites/2007-2013/archiving (accessed November 2017).

51. Dynot (2017) The Dutch education system. https://www. dynot.net/en/education-system-info/dutch-education-sys tem-info (accessed May 2018).

52. Peeters D, Lanting CI \& van Wouwe JP (2015) Peiling melkvoeding van zuigelingen 2015 (Breastfeeding of infants in 2015). https://www.tno.nl/media/5248/peilingmelkvoeding-van-zuigelingen-2015.pdf (accessed June 2018).

53. Nanu MI, Moldovanu F, Novak C et al. (2011) Evaluarea eficienței intervenţiilor incluse în programele naţionale privind nutriţia copiilor sub 2 ani (Evaluating the effectiveness of interventions included in national nutrition programs for children under 2 years of age). https://iomc. ro/uploads/documents/Nutritie-sub-2-ani-raport-final-stu diu.pdf (accessed May 2018).

54. Ministry of Higher Education Science and Technology (2011) Higher education in Slovenia. https://www.google. $\mathrm{dk} / \mathrm{url}$ ? $\mathrm{sa}=\mathrm{t} \& \mathrm{rct}=\mathrm{j} \& \mathrm{q}=\&$ esrc $=\mathrm{s} \&$ source $=$ web $\& \mathrm{~cd}=1 \& \mathrm{cad}=$ rja\&uact $=8 \& v e d=0$ ahUKEwjnvZOe7dTYAhWGKlAKHU Jq DOIQFggpMAA \&url=https\%3A\%2F\%2Fwww.uni-lj.si \%2Fmma\%2FMHEST_CMEPIUS\%2F2013072310281883\% 2F \&usg=AOvVaw0FlauQuYD1AjEJd8RL4DcK (accessed May 2018).

55. Magnusson M, Lagerberg D \& Wallby T (2016) No widening socioeconomic gap within a general decline in Swedish breastfeeding. Child Care Health Dev 42, 415-423.

56. McAndrew F, Thompson J, Fellows L et al. (2012) Infant Feeding Survey 2010. Leeds: Health and Social Care Information Centre.

57. Häggkvist A-P, Brantsæter AL, Grjibovski AM et al. (2010) Prevalence of breast-feeding in the Norwegian Mother and Child Cohort Study and health service-related correlates of cessation of full breast-feeding. Public Health Nutr 13, 2076-2086.

58. Child and Family (2013) Het kind in Vlaanderen 2012 (The child in Flanders 2012). https://www.kindengezin.be/img/ Het_kind_in_Vlaanderen_2012.pdf (accessed May 2018).

59. International Baby Food Action Network (2014) Report on the situation on infant and young child feeding in Croatia. http://ibfan.org/CRC/Croatia\%20CRC67_IBFAN.pdf (accessed May 2018).

60. Medical and Public Health Services, Ministry of Health (2006) Child immunization survey. http://www.oecd.org/ els/family/43136973.xls (accessed May 2018).

61. Organisation for Economic Co-operation and Development, Social Policy Division (2009) Breastfeeding rates. https://www.oecd.org/els/family/43136964.pdf (accessed May 2018).

62. National Institute for Health and Development (2016) Health Statistics and Health Research Database: Fully breastfed infants by breastfeeding duration and county. http://www.tai.ee/en/ (accessed May 2018).

63. Erkkola M, Salmenhaara M, Kronberg-Kippilä C et al. (2010) Determinants of breast-feeding in a Finnish birth cohort. Public Health Nutr 13, 504-513.

64. International Baby Food Action Network (2014) Report on the situation on infant and young child feeding in Hungary. http://tbinternet.ohchr.org/Treaties/CRC/Shared\% 20Documents/HUN/INT_CRC_NGO_HUN_17880_E.pdf (accessed May 2018).
65. Euro-Peristat (2010) Perinatal Health Indicators 2010. http://www.europeristat.com/our-indicators/euro-peristat -perinatal-health-indicators-2010.html (accessed May 2018)

66. Statistics Lithuania (2017) Breastfed children. https://osp. stat.gov.lt/en/lietuvos-vaikai/-/asset_publisher/ypH7pIpX WVRs/content/sveika-1?redirect=http\%3A\%2F\%2Fosp.stat .gov.lt\%2Fen\%2Flietuvos-vaikai\%3Fp_p_id\%3D101_INST ANCE_ypH7pIpXWVRs\%26p_p_lifecycle\%3D0\%26p_p_ state\%3Dnormal\%26p_p_mode\%3Dview\%26p_p_col_id \%3Dcolumn-1\%26p_p_col_pos\%3D3\%26p_p_col_count \%3D4 (accessed June 2016).

67. Center for Lactation Science (2014) Report on breastfeeding status in Poland 2013. http://www.kobiety.med. $\mathrm{pl} / \mathrm{cnol} /$ index.php?option $=$ com_content $\&$ view $=$ article $\& \mathrm{i}$ $\mathrm{d}=153 \&$ Itemid=51\&lang=en (accessed May 2018).

68. Sandes AR, Nascimento C, Figueira J et al. (2007) Breastfeeding: prevalence and determinant factors. Acta Med Port 20, 193-200.

69. Ministry of Health, Social Services and Equality (2016) The National Health Survey, Spain. http://www.ine.es/ss/ Satellite?c=INESeccion_C\&p=1254735110672\&pagename $=$ ProductosYServicios\%2FPYSLayout\&cid $=125992645705$ $8 \& \mathrm{~L}=1$ (accessed May 2018).

70. Gottvall K \& Lundqvist E (2015) Amning och föräldrars rökvanor Barn födda 2013 (Breast-feeding and smoking habits among parents of infants born in 2013, Sweden). http://www.socialstyrelsen.se/Lists/Artikelkatalog/Attach ments/19933/2015-10-9.pdf (accessed May 2018).

71. The Directorate of Health (2012) Breastfeeding and infant nutrition in Iceland born 2004-2008. http://www.child healthresearch.eu/research/add-knowledge/brjostagjof_ og_naering_2004-2008_juni.2012.pdf?set_language=sv\& $\mathrm{cl}=\mathrm{sv}$ (accessed May 2018).

72. International Baby Food Action Network (2011) Report on the situation of infant and young child feeding in the Czech Republic. http://www.ibfan.org/art/IBFAN_CRC572011Czechrep.pdf (accessed May 2018).

73. Bonet M, Marchand L, Kaminski M et al. (2013) Breastfeeding duration, social and occupational characteristics of mothers in the French 'EDEN Mother-Child' cohort. Matern Child Health J 17, 714-722.

74. National Health Information Center (2014) Outpatient care for children and adolescents. http://www.nczisk.sk/ Documents/publikacie/2010/zs1126.pdf (accessed May 2018).

75. Cattaneo A, Burmaz T, Arendt M et al. (2010) Protection, promotion and support of breast-feeding in Europe: progress from 2002 to 2007. Public Health Nutr 13, 751-759.

76. Dyson L, McCormick F \& Renfrew MJ (2005) Interventions for promoting the initiation of breastfeeding. Cochrane Database Syst Rev issue 2, CD001688.

77. Bosi ATB, Eriksen KG, Sobko T et al. (2016) Breastfeeding practices and policies in WHO European region member states. Public Health Nutr 19, 753-764.

78. Wallby T \& Hjern A (2009) Region of birth, income and breastfeeding in a Swedish county. Acta Paediatr 98, 1799-1804.

79. Hasunen K \& Ryynänen S (2006) Imeväisikäisten ruokinta Suomessa vuonna 2005 (Infant feeding in Finland 2005). http://julkaisut.valtioneuvosto.fi/bitstream/handle/10024/ 73836/Selv200519.pdf?sequence=1\&isAllowed=y (accessed May 2018).

80. Laanterä S, Pölkki T, Ekström A et al. (2010) Breastfeeding attitudes of Finnish parents during pregnancy. BMC Pregnancy Childbirth 10, 79.

81. Busck-Rasmussen M, Villadsen SF, Norsker FN et al. (2014) Breastfeeding practices in relation to country of origin among women living in Denmark: a populationbased study. Matern Child Health J 18, 2479-2488. 
82. Baerug A, Laake P, Loland BF et al. (2017) Explaining socioeconomic inequalities in exclusive breast feeding in Norway. Arch Dis Child 102, 708-714.

83. Levinienè G, Tamulevičienè E, Kudzytė J et al. (2013) Factors associated with breastfeeding duration. Medicina (Kaunas) 49, 415-421.

84. Vingras A, Markūnienė E \& Vingraitė J (2005) Kūdikių ir mažu vaiku žindymas: metodiniai nurodymai sveikatos priežiūros specialistams (Breast-feeding of infants and young children: recommendations for health care specialists). http://www.lvb.lt/primo_library/libweb/action/dlDisplay. do?vid=VU\&docId=ELABAPDB3496271\&fromSitemap $=$ $1 \&$ afterPDS=true (accessed May 2018).

85. Organisation for Economic Co-operation and Development, Social Policy Division (2017) Key characteristics of parental leave systems. https://www.oecd.org/els/soc/PF2_1_Par ental_leave_systems.pdf (accessed November 2017).

86. Bonet M, Blondel B \& Khoshnood B (2010) Evaluating regional differences in breast-feeding in French maternity units: a multi-level approach. Public Health Nutr 13, 1946-1954

87. Girard L-C, Côté SM, de Lauzon-Guillain B et al. (2016) Factors associated with breastfeeding initiation: a comparison between France and French-speaking Canada. PLoS One 11, e0166946.

88. International Baby Food Action Network (2016) Report on the situation of infant and young child feeding in France. http://tbinternet.ohchr.org/Treaties/CRC/Shared\%20Docu ments/FRA/INT_CRC_NGO_FRA_22504_E.pdf (accessed May 2018).

89. International Baby Food Action Network Ireland (2016) The best things in life are free suggest Cow and Gate. https:// ibfanireland.wordpress.com/2016/07/15/the-best-things-inlife-are-freesuggest-cow-and-gate/ (accessed May 2018).

90. International Baby Food Action Network (2016) Report on the situation of infant and young child feeding in United Kingdom of Britain and Northern Ireland. http://tbinternet. ohchr.org/Treaties/CESCR/Shared\%20Documents/GBR/ INT_CESCR_CSS_GBR_24015_E.pdf (accessed June 2018).

91. The Council of European Union (2017) Council conclusions to contribute towards halting the rise in childhood overweight and obesity. http://www.consilium.europa. eu/en/press/press-releases/2017/06/16/epsco-childhoodoverweight/ (accessed June 2018).

92. Levinienè G, Petrauskienè A, Tamulevičienė E et al. (2009) The evaluation of knowledge and activities of primary health care professionals in promoting breast-feeding. Medicina (Kaunas) 45, 238-247.

93. Montalto SA, Borg H, Buttigieg-Said M et al. (2010) Incorrect advice: the most significant negative determinant on breast feeding in Malta. Midwifery 26, e6-e13.

94. Nanu MI, Moldovanu F, Stativă E et al. (2011) Evaluarea eficienţei intervenţiilor incluse în programele naţionale privind nutriţia copiilor sub 2 ani (Evaluating the effectiveness of interventions included in national nutrition programs for children under 2 years of age). https://iomc. ro/uploads/documents/Nutritie-sub-2-ani-raport-final-stu diu.pdf (accessed May 2018).
95. Logan C, Zittel T, Striebel S et al. (2016) Changing societal and lifestyle factors and breastfeeding patterns over time. Pediatrics 137, e20154473.

96. Babendure JB, Reifsnider E, Mendias E et al. (2015) Reduced breastfeeding rates among obese mothers: a review of contributing factors, clinical considerations and future directions. Int Breastfeed J 10, 21.

97. Goldade K, Nichter M, Nichter M et al. (2008) Breastfeeding and smoking among low-income women: results of a longitudinal qualitative study. Birth $\mathbf{3 5}$, $230-240$

98. van Rossem L, Vogel I, Steegers EA et al. (2010) Breastfeeding patterns among ethnic minorities: the Generation R Study. J Epidemiol Community Health 64, 1080-1085.

99. Kooijman MN, Kruithof CJ, van Duijn CM et al. (2016) The Generation R Study: design and cohort update 2017. Eur J Epidemiol 31, 1243-1264.

100. Bertini G, Perugi S, Dani C et al. (2003) Maternal education and the incidence and duration of breast feeding: a prospective study. J Pediatr Gastroenterol Nutr 37, $447-452$.

101. Lauria L, Spinelli A \& Grandolfo M (2016) Prevalence of breastfeeding in Italy: a population based follow-up study. Ann Ist Super Sanita 52, 457-461.

102. World Health Organization (2018) Childhood Obesity Surveillance Initiative. http://www.euro.who.int/_data/ assets/pdf_file/0006/372426/wh14-cosi-factsheets-eng.pdf? $\mathrm{ua}=1$ (accessed May 2018).

103. Yan J, Liu L, Zhu Y et al. (2014) The association between breastfeeding and childhood obesity: a meta-analysis. BMC Public Health 14, 1267.

104. Horta BL, Loret de Mola C \& Victora CG (2015) Longterm consequences of breastfeeding on cholesterol, obesity, systolic blood pressure and type 2 diabetes: a systematic review and meta-analysis. Acta Paediatr 104, $30-37$.

105. Dolton P \& Xiao M (2017) The intergenerational transmission of body mass index across countries. Econ Hum Biol 24, 140-152.

106. Baidal JAW, Locks LM, Cheng ER et al. (2016) Risk factors for childhood obesity in the first 1,000 days: a systematic review. Am J Prev Med 50, 761-779.

107. Balogun OO, O'Sullivan EJ, McFadden A et al. (2016) Interventions for promoting the initiation of breastfeeding. Cochrane Database Syst Rev 11, CD001688.

108. United Nations Educational, Scientific and Cultural Organization (1997) International Standard Classification of Education: ISCED 1997. http://www.unesco.org/educa tion/information/nfsunesco/doc/isced_1997.htm (accessed June 2018).

109. Department of Health (2015) Making life better: Monitoring the wider social determinants of health and well being - key indicators 2015. https://www.gov.uk/government/ statistics/making-life-better-monitoring-the-wider-social-de terminants-of-health-and-well-being-key-indicators-2015 (accessed May 2018). 